\title{
CANADA (A.G.) V. PHS COMMUNITY SERVICES SOCIETY THE INSITE DECISION
}

\section{CAMERON WARD*}

\section{INTRODUCTION}

On 30 September 2011, the Supreme Court of Canada rendered a judgment that granted a new lease on life to Vancouver's Insite, North America's first, and still only, supervised safe drug injection facility. ${ }^{1}$ The unanimous decision on important issues of constitutional law resolved an unseemly federal-provincial squabble over drug addiction treatment policy and arguably paved the way for a more liberal approach to a problem that has plagued Canada's inner cities for decades. The Court's analysis of traditional principles surrounding the division of powers and the application of the Canadian Charter of Rights and Freedoms ${ }^{2}$ to governmental action will undoubtedly provide some future guidance to lawyers and judges as they wrestle with other cases where issues of morality and law may intersect.

\section{BACKGROUND}

The intersection of Main and Hastings streets is the epicenter of one of Canada's grittiest neighbourhoods. The area known as the downtown east side (DTES) of Vancouver, often characterized as “Canada's poorest postal code," is home to people with a constellation of problems that make their daily lives exceedingly difficult. The residents of this community struggle with issues of poverty, homelessness, drug and alcohol addiction, disease, crime, prostitution, and racism every day of their lives while the more affluent residents of the rest of the city remain largely indifferent to their plight. In particular, intravenous drug trafficking and use has always been rampant, with both activities taking place openly within a block of the former police headquarters at 312 Main Street. The reaction of the Vancouver police to the plight of the vulnerable and marginalized residents of the DTES vacillates between indifference and outright abuse and harassment. ${ }^{3}$

In this context, any "war on drugs" was unwinnable. The provincial courthouse at 222 Main Street became inundated with people facing charges arising from their dependence on drugs. In addition to possession offences, the dockets fairly often overflowed with cases of petty theft, breaches of conditions, and breaches of probation. Furthermore, the chief coroner sounded the alarm, as early as 1994, that people were dying unnecessarily, the victims of overdose or the spread of disease caused by sharing unsanitary injection equipment. By 1997, many reasonable people realized that drug-related problems in the DTES had reached crisis proportions and that something needed to be done.

A Cameron Ward \& Company, Barristers \& Solicitors, Vancouver, British Columbia Canada (AG) v PHS Community Services Society, 2011 SCC 44, [2011] 3 SCR 134 [PHS].

Part 1 of the Constitution Act, 1982, being Schedule B to the Canada Act 1982 (UK), 1982, c 11 [Charter].

This is exemplified by the fact that two recent public inquiries into police conduct, the Davies Commission Inquiry into the Death of Frank Paul and the Missing Women Commission of Inquiry, have investigated the deaths of addicted members of the DTES community. 
Eventually, something was done. Vancouver's regional health authority resolved to open, and the federal Minister of Health approved an exemption from sections 4(1) and 5(1) of the Controlled Drugs and Substances Act ${ }^{4}$ for, a supervised drug injection facility modeled after successful operations in Europe and Australia. Insite opened its doors on 12 September 2003.

Insite maintains an unassuming storefront location next to an adult entertainment shop on Hastings Street, just west of Main. On its other side, a door leads upstairs to "Onsite,” an associated detoxification facility where nurses, physicians, and counselors provide assistance to anyone seeking to attempt to defeat a substance addiction. Insite itself has twelve semiprivate bays where a user may take the clean injection equipment provided by staff and prepare and inject drugs that the user has acquired from the streets. Insite staff record, supervise, and monitor the drug injection activities there; they do not actually administer the substances.

It is a testament to Insite's success that, although there have been hundreds of drug overdoses at the facility, not a single person has died there. This is undoubtedly due to the immediate availability of paramedical resources.

Since Insite's staff and clients engage in or facilitate conduct that could be considered criminal under the provisions of the CDSA, its operations depend upon a ministerial exemption granted under section 56 of the CDSA, which provides:

\footnotetext{
The Minister may, on such terms and conditions as the Minister deems necessary, exempt any person or class of persons or any controlled substance or precursor or any class thereof from the application of all or any of the provisions of this Act or the regulations if, in the opinion of the Minister, the exemption is necessary for a medical or scientific purpose or is otherwise in the public interest.
}

Insite received its first section 56 exemption from the federal Liberal government before it opened in 2003. That exemption had a three year term, which was subsequently extended to expire on 31 December 2007. Insite's foothold in the DTES had become more tenuous after the 2006 general election that installed a Conservative government in Ottawa. When it appeared that the federal government would no longer commit to the continued operation of the facility, Insite's operators and clients turned to the courts. The first of two civil actions, Vancouver Area Network of Drug Users (VANDU) v. Attorney General of Canada and Minister of Health for Canad $a,{ }^{5}$ was commenced in 2006 while the second, PHS Community Services Society et al. v. Attorney General of Canada, ${ }^{6}$ was filed in August 2007, shortly before the exemption extension was scheduled to lapse. 


\section{Procedural History}

\section{A. Trial}

Both cases were tried together in summary fashion by Justice Pitfield of the Supreme Court of British Columbia under the Court's rules of procedure that permit some cases to be determined on affidavit evidence. ${ }^{7}$ The federal government used the considerable resources at its disposal to defend the cases vigorously. Its lawyers first raised the procedural objection that the issues were unsuitable for summary disposition and that viva voce evidence would be necessary. The trial judge sidestepped this issue deftly by concluding that he "could not finally rule on Canada's objection with fairness to the parties without considering all of the affidavit evidence and hearing the submissions of counsel in relation to it." ${ }^{8}$ Eight hearing days later, counsel for the federal government had resiled somewhat from their original position, and the preliminary objection was ultimately dismissed.

After a short period under reserve, the Court's written decision was released on 27 May 2008. Justice Pitfield made findings of fact that would ultimately prove central to the disposition of the issues raised in the litigation. He concluded that

all of the evidence adduced by PHS, VANDU and Canada supports some incontrovertible conclusions:

1. Addiction is an illness. One aspect of the illness is the continuing need or craving to consume the substance to which the addiction relates.

2. Controlled substances such as heroin and cocaine that are introduced into the bloodstream by injection do not cause Hepatitis C or HIV/AIDS. Rather, the use of unsanitary equipment, techniques, and procedures for injection permits the transmission of those infections, illnesses or diseases from one individual to another; and

3. The risk of morbidity and mortality associated with addiction and injection is ameliorated by injection in the presence of qualified health professionals. ${ }^{9}$

Justice Pitfield went on to say, "[r]esidents of the DTES who are addicted to heroin, cocaine, and other controlled substances are not engaged in recreation. Their addiction is an illness frequently, if not invariably, accompanied by serious infections and the real risk of overdose that compromise their physical health and the health of other members of the public."10

Having cast the principal factual issue as one of health and safety, the trial judge identified and determined three legal issues. He dismissed VANDU's application for a declaration that the activities of Insite's staff did not constitute criminal conduct (possession or trafficking) on the basis that exercising the Court's discretionary power in respect of future events would

PHS Community Services Society v Canada (AG), 2008 BCSC 661, 293 DLR (4th) 392 [PHS (BCSC)]. See British Columbia, Supreme Court Civil Rules, r 59.

PHS (BCSC), ibid at para 10.

Ibid at para 87.

Ibid at para 89. 
constitute a declaration "in the air" that would serve no useful purpose. ${ }^{11}$ Next, Justice Pitfield addressed the claim of VANDU and PHS that the doctrine of interjurisdictional immunity, properly applied, meant that the provisions of the CDSA prohibiting the possession and trafficking of controlled substances (sections 4 and 5) could not intrude on a health care undertaking within the core of provincial jurisdiction over health care. The trial judge found that the federal power to legislate in relation to criminal law met head-on with the provincial power to provide health care services such that the case presented a classic “double aspect” problem. ${ }^{12}$ By acknowledging dicta from the Supreme Court of Canada suggesting that the doctrine of interjurisdictional immunity should be used sparingly, and by applying the doctrine of paramountcy, Justice Pitfield concluded that the criminal law should prevail, subject to Charter considerations. ${ }^{13}$ He dismissed the plaintiffs' arguments on this ground and then turned to the Charter issues.

The Court asked whether "the criminalization of the possession of controlled substances within the premises of the Vancouver Safe Injection Site violate[s] s. 7 of the Charter of Rights and Freedoms."14

Justice Pitfield distinguished earlier decisions of the Ontario Court of Appeal ${ }^{15}$ and Supreme Court of Canada $^{16}$ dealing with the prohibitions in the context of marijuana possession and concluded that sections 4(1) and 5(1) of the CDSA infringed life, liberty, and security of the person and could not be saved by section 1 of the Charter. He declared the provisions to be of no force and effect and suspended the effect of the declaration until 30 June 2009. ${ }^{17}$

\section{B. Court of AppeAL}

The federal government's appeal and the plaintiffs' cross-appeals were heard by the Court of Appeal for British Columbia from 27-29 April 2009 and the appellate court's reserved judgment was pronounced on 15 January 2010. The three Court of Appeal justices disagreed in their analysis of the issues and a divided court rendered a decision dismissing the appeal and allowing the cross-appeal.

Justice Rowles concurred with Justice Huddart's conclusion that the doctrine of interjurisdictional immunity applied. ${ }^{18}$ Justice Huddart noted that Insite was a provincial health care facility akin to a hospital and opined that the federal government could not interfere with the determination of the nature of services the facility would provide to its patients. She reasoned that the province had the exclusive ability to respond to the health care crisis extant in Vancouver and that a "surgical," or precisely defined, application of the doctrine would not amount to "provincial paramountcy."19

Ibid at paras 98-99.

Ibid at para 117.

Ibid at para 120 .

Ibid at para 122.

$R v$ Parker (2000), 49 OR (3d) 481 (CA).

$R v$ Malmo-Levine; $R$ v Caine, 2003 SCC 74, [2003] 3 SCR 571.

PHS (BCSC), supra note 7 at paras 158-59.

PHS Community Services Society v Canada (AG), 2010 BCCA 15, 314 DLR (4th) 209 at para 78 [PHS (BCCA)].

Ibid at para 175. 
Justice Rowles agreed with the trial judge's disposition of the Charter issue, although she found that the impugned provisions of the CDSA, as applied to Insite, were overbroad rather than arbitrary. She found that the application of sections 4(1) and 5(1) would not be in accordance with the principles of fundamental justice because of the grossly disproportionate effect on those using the facility. As she put it:

Without Insite, addicts will be forced back into the alleys and flophouses where they will continue to inject hard drugs, but in squalid conditions, thereby risking illness and death, not only to themselves but also to others in the community who become infected through the sharing of dirty needles or through intimate contact with an infected person. ${ }^{20}$

Justice Smith dissented on both issues. She found that the plaintiffs had failed to establish that the deprivation of their section 7 Charter rights was not in accordance with the principles of fundamental justice and that the impugned provisions of the CDSA were not arbitrary, disproportionate, or overbroad. She agreed with the trial judge's conclusion that the doctrine of interjurisdictional immunity should not apply.

The Court of Appeal's majority decision meant that Insite would continue to remain in operation, subject to the result of any further appeal to the Supreme Court of Canada.

\section{Supreme COURT OF CANAdA}

Not surprisingly, lawyers for the federal government received instructions to seek leave to appeal the Court of Appeal's decision and, on 24 June 2010, the Supreme Court of Canada granted the application. The Court also gave leave to intervene to 14 applicants, all but one of whom supported the continued operation of Insite in their written and oral submissions. The appeal was heard on 12 May 2011 and judgment was reserved.

On 26 September 2011, the Court announced that its judgment would be released on 30 September 2011. For four days, the proponents of Insite awaited the decision with a mixture of hope and dread. A substantial crowd gathered outside the Hastings Street premises in the darkness early on the Friday morning, ready to celebrate or protest depending on the result (the time difference between the Pacific and Eastern zones meant that the decision would be pronounced in Ottawa just after 6:30 a.m. in Vancouver).

Most lawyers immediately flip to the end of written reasons for judgment to obtain the result before embarking on a more leisurely and careful analysis of how the court actually disposed of the issues in the case. The last line said simply, "Appeal dismissed with costs. Cross-appeal dismissed without costs." ${ }^{21}$ A page before the end, paragraph 156 of the reasons provided some elaboration:

The CDSA is constitutionally valid and applies to the activities at Insite. However, the Minister of Health's actions in refusing to exempt Insite from the operation of the CDSA are in violation of the respondents' s.

7 Charter rights. The Minister is ordered to grant an exemption for Insite under s. 56 of the CDSA. 
It turned out that Chief Justice McLachlin, writing for the Court, had rejected the conclusions of the majority of the Court of Appeal on both the division of powers and Charter issues.

\section{DIVISION OF POWERS}

By the time the case reached the Supreme Court of Canada, a new argument had been added to the mix by the intervenors, in addition to the issue of the doctrine of interjurisdictional immunity raised in the first instance. The Attorney General of Quebec argued that sections 4(1) and 5(1) of the CDSA were ultra vires the federal government's power to enact criminal law, at least insofar as they prohibited drugs dispensed in a medical context. $^{22}$ The Court had little trouble with the admittedly novel argument, concluding that the impugned provisions were validly enacted. ${ }^{23}$

The Attorney General of British Columbia again submitted that sections 4(1) and 5(1) of the CDSA should be read as inapplicable to Insite, arguing that "once a province establishes that a particular activity... serves the public interest, that activity is exempt from the operation of federal criminal laws.”24 The Court held that existing authority did not support this reasoning and rejected the argument.

The plaintiffs, now supported by the Attorney General of British Columbia, again advanced the argument that had been rejected by the trial judge but accepted by a majority of the Court of Appeal, that is, that "Insite is shielded from the operation of the CDSA by virtue of the doctrine of interjurisdictional immunity." ${ }^{25}$ The Court spent additional time and ink on this issue. It noted that the doctrine is indeed to be employed cautiously and sparingly and said that "[w]hile [it] has been narrowed, it has not been abolished." ${ }^{26}$ According to the Court, it should not be applied in a new area if the constitutional issue can be resolved on another basis. In this case, the Court characterized the question as being "whether the delivery of health care services constitutes a protected core of the provincial power over health care in s. 92(7), (13) and (16) of the Constitution Act, 1867, and is therefore immune from federal interference." 27 The Court concluded that, for several reasons, the question had to be answered in the negative and signaled how similar issues might be treated in the future:

In summary, the doctrine of interjurisdictional immunity is narrow. Its premise of fixed watertight cores is in tension with the evolution of Canadian constitutional interpretation towards the more flexible concepts of double aspect and cooperative federalism. To apply it here would disturb settled competencies and introduce uncertainties for new ones. Quite simply, the doctrine is neither necessary nor helpful in the resolution of the contest here between the federal government and the provincial government. ${ }^{28}$

Ibid at para 50 .

Ibid at para 52.

Ibid at para 53.

Ibid at para 57.

Ibid at para 65.

Ibid at para 66.

Ibid at para 70. 


\section{The Charter}

The Court found that the prohibition on possession of controlled substances contained in section 4(1) of the CDSA does limit the rights of the staff and clients of Insite under section 7 of the Charter, but the prohibition in section 5(1) did not, since the activities occurring at the facility could not be construed as trafficking. ${ }^{29}$ However, the Court considered that section 56 of the CDSA acted as a "safety valve" 30 and meant that the limitation was not arbitrary, disproportionate in its effects, or overbroad. The availability of ministerial discretion brought the limit imposed by section 4(1) into accordance with the principles of fundamental justice and saved it under section 1 of the Charter.

Although the Court upheld the constitutionality of the impugned provisions of the CDSA, that did not end the Charter inquiry. The Court went on to examine the Minister's exercise of the power to grant exemptions on the basis that his discretion was not absolute and had to be in conformity with the Charter.

An interesting factual question arose: had the Minister actually decided not to extend the exemption that would allow Insite to continue operating? The plaintiffs had commenced the litigation while under an apprehension that the Minister would probably not further extend the exemption. The Minister had granted a third temporary extension that was scheduled to expire on 30 June 2008. However, the trial decision pronounced in May 2008 and upheld by the appellate court two years later had effectively allowed the facility to continue its uninterrupted service to the community without obliging the Minister to address the issue further.

On 29 May 2008, after the trial decision had been rendered, Minister of Health Tony Clement had made public statements that were critical of Insite, including that "the site itself represents a failure of public policy." ${ }^{11}$ The Court construed these statements as a de facto decision to refuse any further application for an exemption. It found that the ministerial decision was both arbitrary, undermining the health and safety purposes of the CDSA, and grossly disproportionate in its effects, thus violating the plaintiffs' section 7 Charter rights in a manner that could not be justified under section 1 .

The Court concluded that it had a broad discretion to craft an appropriate remedy and that, "[i]n the special circumstances of this case, an order in the nature of mandamus is warranted." 32 The history of the proceedings suggested that "[t]here is therefore nothing to

\footnotetext{
$29 \quad$ Ibid at para 95.

30 Ibid at para 113

31 House of Commons, Standing Committee on Health, Evidence (29 May 2008) at 18 (Chair: Joy Smith), online: Parliament of Canada <http://www.parl.gc.ca/content/hoc/committee/392/HESA/Evidence/EV 3529880/HESAEV32-E.PDF>. Surprisingly, Minister Clement made these comments in spite of the final report of the Expert Advisory Committee, which had been delivered to him on 31 March 2008: see Expert Advisory Committee, Vancouver's INSITE service and other Supervised injection sites: What has been learned from research? (31 March 2008), online: Health Canada <http://www.hc-sc.gc. ca/ahcasc/pubs/_sites-lieux/insite/index-eng.php>. The Committee's consensus was overwhelmingly favourable.

32 PHS, supra note 1 at para 150.
} 
be gained (and much to be risked) in sending the matter back to the Minister for reconsideration." 33

\section{COMMENTARY}

The first striking feature of the Supreme Court of Canada's decision is that it was based on a factual ground (ministerial action) that was not the focus when the case was tried in the first instance and only really crystallized later. The second extraordinary aspect was the nature of the remedy, which contrasted starkly with the disposition in Omar Khadr's case ${ }^{34}$ a year before. There, the Court concluded that the federal government had been complicit in violating Khadr's section 7 Charter rights, but declined to order that the government request Khadr's return, instead simply making a declaration that his rights had been infringed and leaving it to the federal government to respond appropriately. ${ }^{35}$ Khadr was not returned to Canada, but faced trial in Guantanamo Bay, where he was convicted of war crimes and terrorism. $^{36}$

To some commentators, the judgment in PHS signaled a new wave of unwelcome judicial intervention in governmental policy making. To others, including this writer, it drives home the inescapable reality that the Charter is the supreme law of the land - law that cannot be ignored with impunity. The decision has narrow consequences for the future formulation of drug policy and broader implications for other governmental action and decision-making.

The Supreme Court of Canada's decision did not fling the doors open to enable safe injection sites to spring up all across the country. By the same token, it did not preclude the possibility of further facilities being established if they could be justified on evidentiary grounds similar to those established in this case. The health and safety of other vulnerable and marginalized populations will be enhanced if similar sites are established elsewhere; their proponents will need to look carefully at this decision and the evidentiary record created by the plaintiffs for their successful litigation.

The decision has closed the door further on the doctrine of interjurisdictional immunity, at least when it is invoked to attempt to validate the exercise of provincial powers. It is difficult to imagine how the concept could be applied in the future. As Justice Huddart concluded in the lower appellate court, "[i]f interjurisdictional immunity is not available to a provincial undertaking on the facts of this case, then it may well be said the doctrine is not reciprocal and can never be applied to protect exclusive provincial powers." ${ }^{37}$ Federal authorities will continue to hold the upper hand in areas of mixed responsibility and "cooperative federalism” will remain the means to address the tensions that may arise.

The judgment may have implications for the vexing issues surrounding the application of the CDSA to the production, trafficking, and possession of marijuana. While the Marihuana

Ibid.

Canada (Prime Minister) v Khadr, 2010 SCC 3, [2010] 1 SCR 44.

Ibid at para 39.

“Omar Khadr sentenced to symbolic 40 years,” CBC News (31 October 2010), online: CBC News <http://www.cbc.ca/news/world/story/2010/10/31/guantanamo-khadr-sentencing.html>.

PHS (BCCA), supra note 18 at para 176. 
Medical Access Regulations ${ }^{38}$ constitute Parliament's attempt to address the therapeutic use of marijuana, the regulations vest some discretion in the Minister when considering whether to grant applications for an appropriate licence. It is difficult to distinguish (although Justice Pitfield did) the use of marijuana for treatment of an illness from the use of injection drugs in response to the illness of addiction. Consequently, there may be cases where the courts are called upon to review the Minister's decisions in this context.

Other scenarios arise. For example, a Canadian inmate on Montana's death row is currently complaining that the federal government has not done enough to support his bid for clemency. The Federal Court, Trial Division determined a judicial review application in the inmate's favour, but declined to consider Charter issues on the basis that they would be "speculative." 39 The Court ordered the government to apply its former policy of supporting clemency for any Canadian facing execution in a foreign land. The government responded by submitting a letter to the American authorities, but it has widely been perceived as a lukewarm request. Quaere whether the inmate could rely on PHS to seek a declaration that his Charter rights will be infringed by his execution and that the Court should force the Minister to take further steps.

Extradition cases arise where a Canadian citizen may be subjected to cruel and inhuman punishment, in the form of torture or death, if the foreign state's extradition request is granted. In the past, the Supreme Court of Canada has ordered the federal government to request an assurance that the death penalty will not be sought before extraditing a Canadian fugitive. ${ }^{40}$ The $P H S$ decision increases the certainty that such an approach will be adopted again in the future.

The appropriateness of death as punishment for some criminal offences, or torture as a means of intelligence gathering, involves, at least at some level, the exercise of moral judgment rather than the application of black letter law. Governments frequently make value judgments on a host of activities that, unlike the previous examples, do not necessarily involve infringements on public health or safety. Although then Minister of Justice Pierre Trudeau famously said in 1967, "there's no place for the state in the bedrooms of the nation," ${ }^{41}$ governments have rarely shirked from attempting to deal with issues of morality. PHS will likely reverberate whenever courts consider anew the validity of laws governing such issues as prostitution, marriage, indecency, abortion, distribution of pornography, euthanasia, genetic engineering, and a host of other issues. With its decision in this case, the Supreme Court of Canada has clearly signaled, to government and to the rest of us, that it is prepared to apply the Charter to make the ultimate determination between right and wrong.

SOR/2001-227.

Smith $v$ Canada (AG), 2009 FC 228 at para 58.

See e.g. United States v Burns, 2001 SCC 7, [2001] 1 SCR 283.

“Omnibus Bill: 'There's no place for the state in the bedrooms of the nation',” CBC Digital Archives, online: CBC Digital Archives <http://www.cbc.ca/archives/categories/politics/rights-freedoms/trudeausomnibus-bill-challenging-canadian-taboos/theres-no-place-for-the-state-in-the-bedrooms-of-thenation.html>. 